\title{
Effects of $\mathrm{OH}^{-}$activity and temperature on the dissolution rate of compacted montmorillonite under highly alkaline conditions
}

\author{
TAKUMA SAWAGUCHI*, MANABU TSUKADA, TETSUJI YAMAGUCHI AND \\ MASAYUKI MUKAI \\ Waste Safety Research Group, Nuclear Safety Research Center, Japan Atomic Energy Agency, Tokai, Ibaraki 319-1195, \\ Japan
}

(Received 31 May 2015; revised 18 December 2015; Guest editor: Reiner Dohrmann)

\begin{abstract}
The highly alkaline environment induced by cementitious materials in a deep geological disposal system of high-level radioactive waste is likely to alter montmorillonite, the main constituent of bentonite buffer materials. Over long time periods, the alteration may cause the physical and/or chemical barrier functions of the buffer materials to deteriorate. In order to evaluate the long-term alteration behaviour, the dissolution rate, $R_{\mathrm{A}}\left(\mathrm{kg} \mathrm{m}^{-3} \mathrm{~s}^{-1}\right)$, of compacted pure montmorillonite (Kunipia-F) was investigated experimentally under conditions of hydroxide ion concentration of $0.10-1.0 \mathrm{~mol} \mathrm{dm}^{-3}$ at temperatures of $50-90^{\circ} \mathrm{C}$. The dissolution rate data, including those from a previous study at $130^{\circ} \mathrm{C}$, were formulated as a function of the activity of hydroxide ions, $a_{\mathrm{OH}^{-}}\left(\mathrm{mol} \mathrm{dm}^{-3}\right)$, and temperature, $T(\mathrm{~K})$, and expressed as $R_{\mathrm{A}}=10^{4.5} \cdot\left(a_{\mathrm{OH}^{-}}\right)^{1.3} \cdot e^{-55000 / \mathrm{RT}}$ by multiple regression analysis, where $\mathrm{R}$ is the gas constant. The dissolution rate of montmorillonite was greater in the compacted montmorillonite than in the compacted sand-bentonite mixtures. The difference can be explained by considering the decrease in $a_{\mathrm{OH}^{-}}$ in the mixtures accompanied by dissolution of accessory minerals such as quartz and chalcedony. The dissolution rate model developed for pure montmorillonite is expected to be applied to bentonite mixtures if quantification of the decrease in $a_{\mathrm{OH}^{-}}$is achieved somehow.
\end{abstract}

KEYWORDS: compacted montmorillonite, highly alkaline conditions, dissolution rate, activity of hydroxide ions, temperature, accessory minerals.

Highly alkaline environments induced by cementitious materials in a deep geological disposal system for highlevel radioactive waste are likely to alter montmorillonite, the main constituent of bentonite buffer materials, affecting adversely the physical and/or chemical barrier functions of the buffer materials. In order to evaluate the long-term alteration behaviour, the dissolution rate of montmorillonite should be determined.

*E-mail: sawaguchi.takuma@jaea.go.jp

DOI: $10.1180 /$ claymin.2016.051.2.12
Various studies on the dissolution rates of clays in alkaline solutions used different pulverized smectites (Savage et al., 1992; Bauer \& Berger, 1998; Kubo et al., 1998; Sato et al., 2004; Rozalén et al., 2008, 2009), and determined the rates under much lower solid/solution ratios than those of the disposal sites (Table 1). These data need some modification in order to evaluate the dissolution of buffer materials under the confined disposal conditions. Savage \& Liu (2015) reported that the most relevant water/clay ratio ('porosity') should be used in modelling and experimental systems based on thermodynamic calculations illustrating that the water/clay ratio affected the magnitude and nature of 


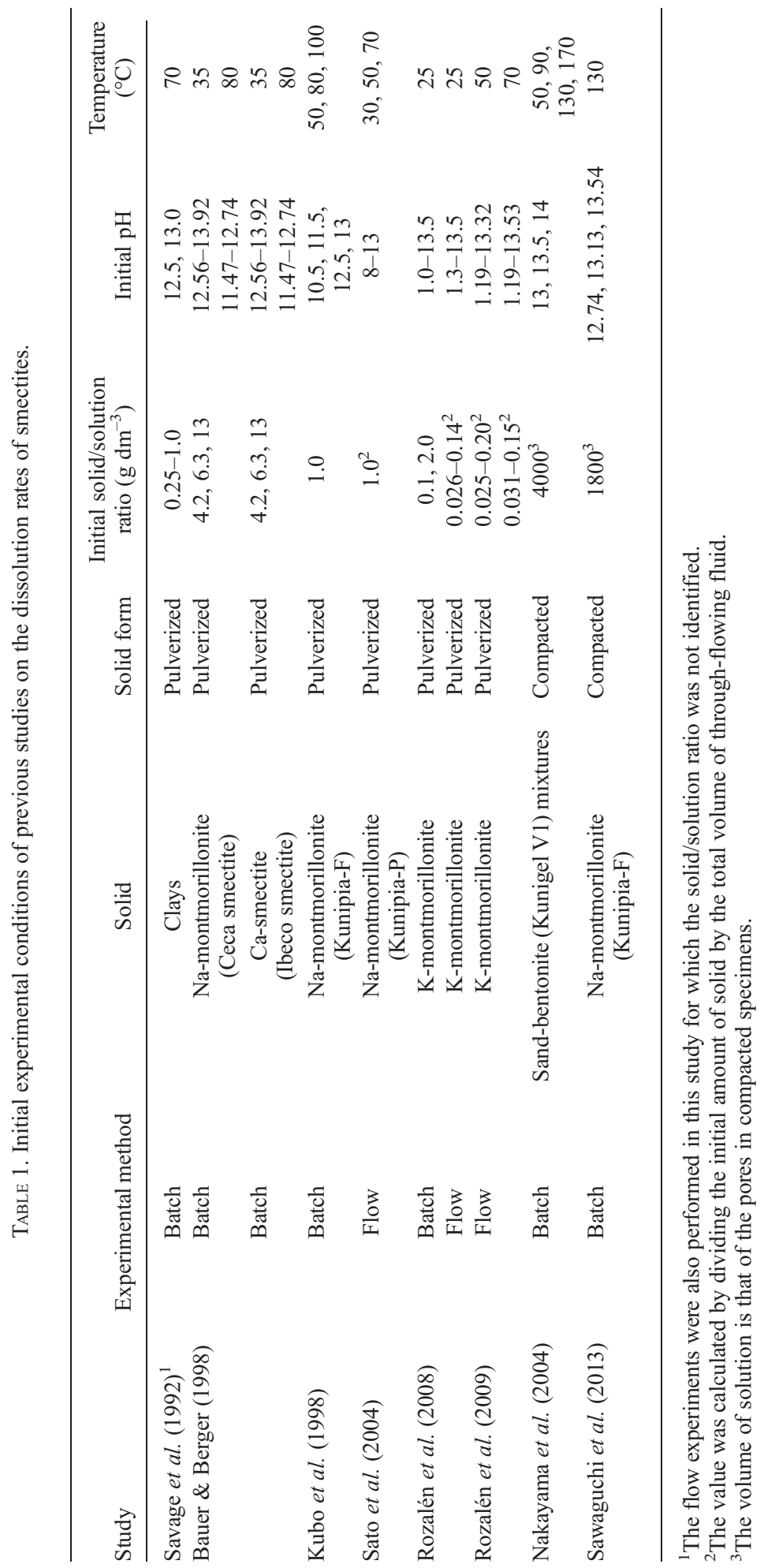


TABLE 2. Chemical composition of highly alkaline solutions for the alteration experiment.

\begin{tabular}{lcccccc}
\hline & \multicolumn{5}{c}{ Concentration $\left(\mathrm{mol} \mathrm{dm}^{-3}\right)$} \\
\cline { 2 - 6 } & \multicolumn{5}{c}{ Alteration temperature } \\
\cline { 2 - 7 } Element & $50^{\circ} \mathrm{C}$ & \multicolumn{7}{c}{$70^{\circ} \mathrm{C}$} & $90^{\circ} \mathrm{C}$ \\
\hline $\mathrm{OH}^{-}$ & 1.0 & 0.30 & 1.0 & 0.10 & 0.30 & 1.0 \\
$\mathrm{Na}$ & 1.1 & 1.1 & 1.1 & 1.1 & 1.1 & 1.1 \\
$\mathrm{Al}$ & $2.6 \times 10^{-3}$ & $1.1 \times 10^{-3}$ & $2.4 \times 10^{-3}$ & $1.3 \times 10^{-3}$ & $1.8 \times 10^{-3}$ & $2.6 \times 10^{-3}$ \\
$\mathrm{Ca}$ & $1.0 \times 10^{-4}$ & $1.3 \times 10^{-4}$ & $6.0 \times 10^{-5}$ & $1.0 \times 10^{-4}$ & $1.2 \times 10^{-4}$ & $1.7 \times 10^{-5}$ \\
$\mathrm{Si}$ & $2.7 \times 10^{-2}$ & $3.0 \times 10^{-2}$ & $3.1 \times 10^{-2}$ & $3.1 \times 10^{-2}$ & $2.6 \times 10^{-2}$ & $2.9 \times 10^{-2}$ \\
$\mathrm{pHe}$ & 13.81 & 13.38 & 13.80 & 12.76 & 13.34 & 13.81 \\
\hline & & & & & & \\
\hline
\end{tabular}

${ }^{1} \mathrm{The}$ 'pHe' is a measured value of $\mathrm{pH}$ using a $\mathrm{ROSS}{ }^{\circledR}$ combination-glass $\mathrm{pH}$ electrode at room temperature $\left(\sim 25^{\circ} \mathrm{C}\right)$.

alteration. The dissolution rates in compacted sandbentonite mixtures were determined experimentally and formulated under hydroxide ion activities, $a_{\mathrm{OH}^{-}}$, of $0.04-0.57 \mathrm{~mol} \mathrm{dm}^{-3}$ and temperatures of $50-170^{\circ} \mathrm{C}$ (Nakayama et al., 2004; Yamaguchi et al., 2007). The dissolution rates in the mixtures, however, were smaller than that in pulverized montmorillonite and depended more heavily on $a_{\mathrm{OH}^{-}}$. Yamaguchi et al. (2007) suggested that different $a_{\mathrm{OH}}-$ in pore water from that in the external solution might be responsible for this dependence, although this was not verified. Sawaguchi et al. (2013) studied the dissolution rates of compacted pure montmorillonite at $130^{\circ} \mathrm{C}$ and showed greater dissolution rates than those in the mixtures. The explanation given for the difference was that the dissolution of montmorillonite in the mixtures was inhibited by decreasing the $a_{\mathrm{OH}}-$ stemming from the dissolution of accessory minerals such as $\mathrm{SiO}_{2}$ polymorphs (quartz, chalcedony, etc.) in the mixtures.

In the present study, the dependence of the dissolution rate of compacted montmorillonite (Kunipia-F) on $\mathrm{OH}^{-}$activity and temperature were investigated experimentally to clarify the effect of accessory minerals on the dissolution rate under compaction.

\section{EXPERIMENTAL}

The dissolution rate for montmorillonite under compaction was obtained through a time-dependent variation in the amount of remaining montmorillonite in the compacted montmorillonite altered by highly alkaline solution. The experimental method was the same as in previous studies (Nakayama et al., 2004; Yamaguchi et al., 2007; Sawaguchi et al., 2013) and

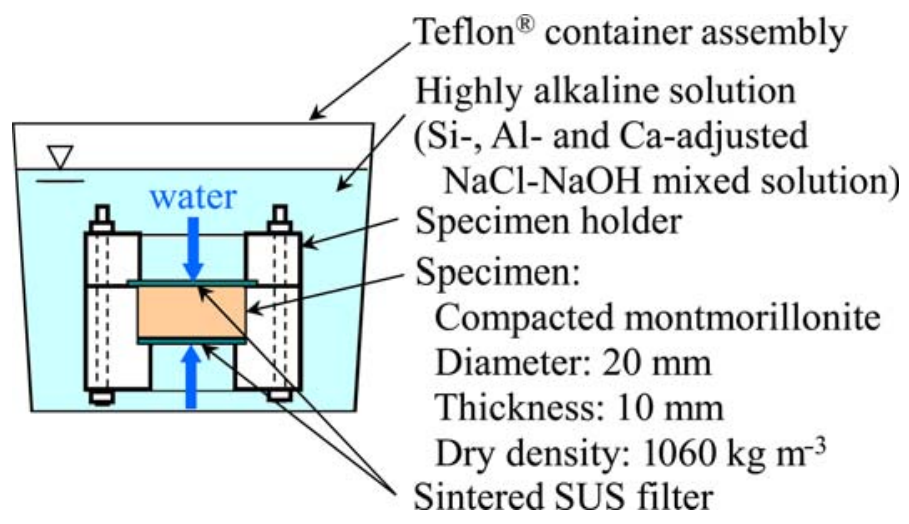

FIG. 1. Schematic drawing of the experimental configuration of the saturation process before the alteration of compacted montmorillonite. 

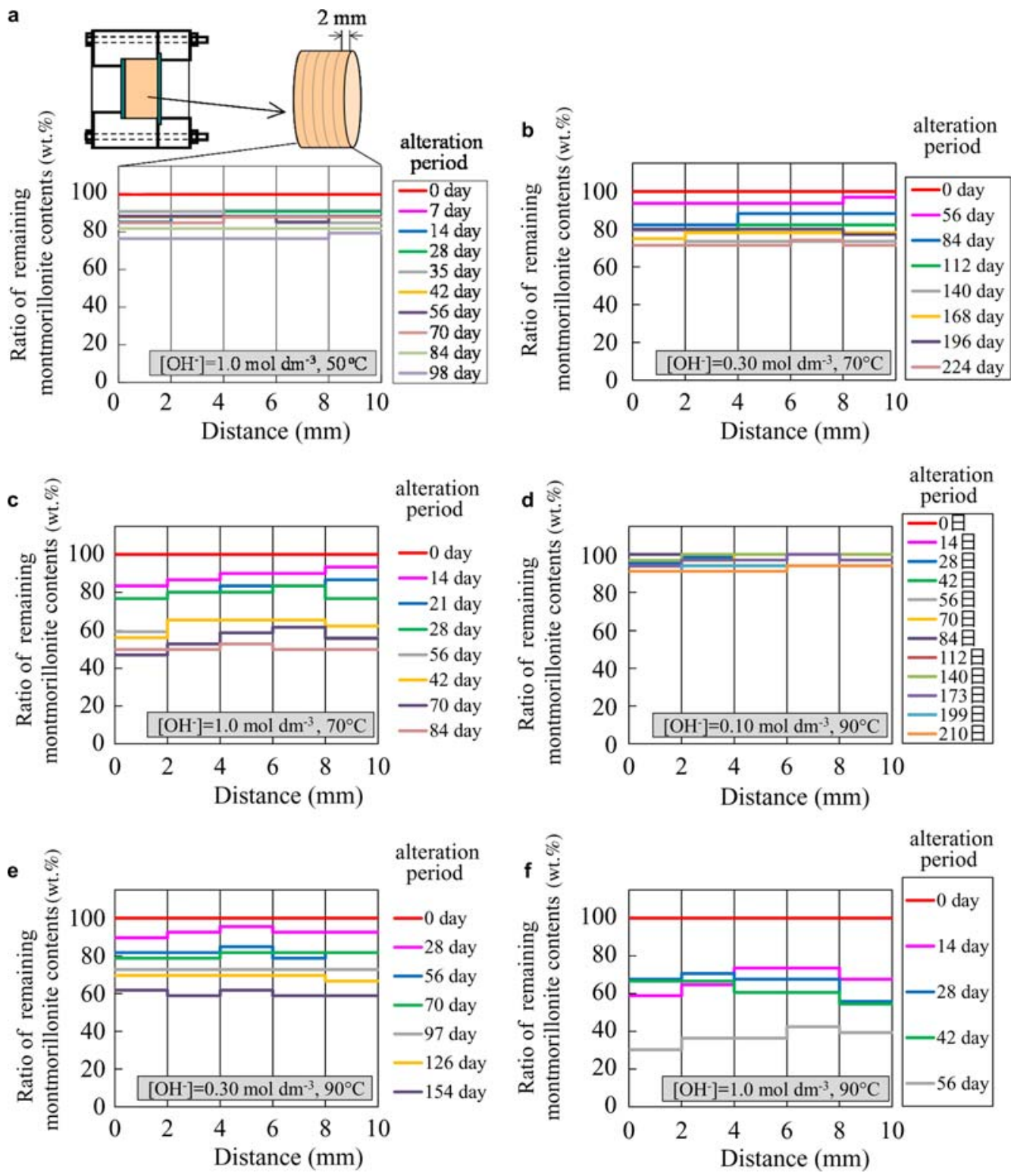

FIG. 2. Spatial distribution of weight ratio of remaining montmorillonite contents in the specimen altered by the alkaline solutions. (a) $\mathrm{OH}^{-}$concentration of $1.0 \mathrm{~mol} \mathrm{dm}^{-3}$ at $50^{\circ} \mathrm{C}$, (b) $0.30 \mathrm{~mol} \mathrm{dm}^{-3}$ at $70^{\circ} \mathrm{C}$, (c) $1.0 \mathrm{~mol} \mathrm{dm}^{-3}$ at $70^{\circ} \mathrm{C}$, (d) $0.10 \mathrm{~mol} \mathrm{dm}^{-3}$ at $90^{\circ} \mathrm{C}$, (e) $0.30 \mathrm{~mol} \mathrm{dm}^{-3}$ at $90^{\circ} \mathrm{C}$, and (f) $1.0 \mathrm{~mol} \mathrm{dm}{ }^{-3}$ at $90^{\circ} \mathrm{C}$.

the experimental conditions were the same as in a previous study by the present authors (Sawaguchi et al., 2013), except for the temperature conditions.

The montmorillonite (Kunipia-F, a commercial product of Kunimine Industries Co. Ltd., Japan) was compacted in specimen holders to obtain a dry density of $1060 \mathrm{~kg} \mathrm{~m}^{-3}$ or porosity of 0.6 . The porosity of 0.6 was selected by considering porosity variations of 0.4-0.8 through the experiment for the mixtures (Nakayama et al., 2004). The Si-, Al- and Ca-adjusted $\mathrm{NaCl}-\mathrm{NaOH}$ mixed solutions used in the previous experiment (Nakayama et al., 2004) were also used in the present study (Table 2). The alkaline solutions were prepared by adding $\mathrm{NaCl}, \mathrm{NaOH}$, sodium metasilicate 

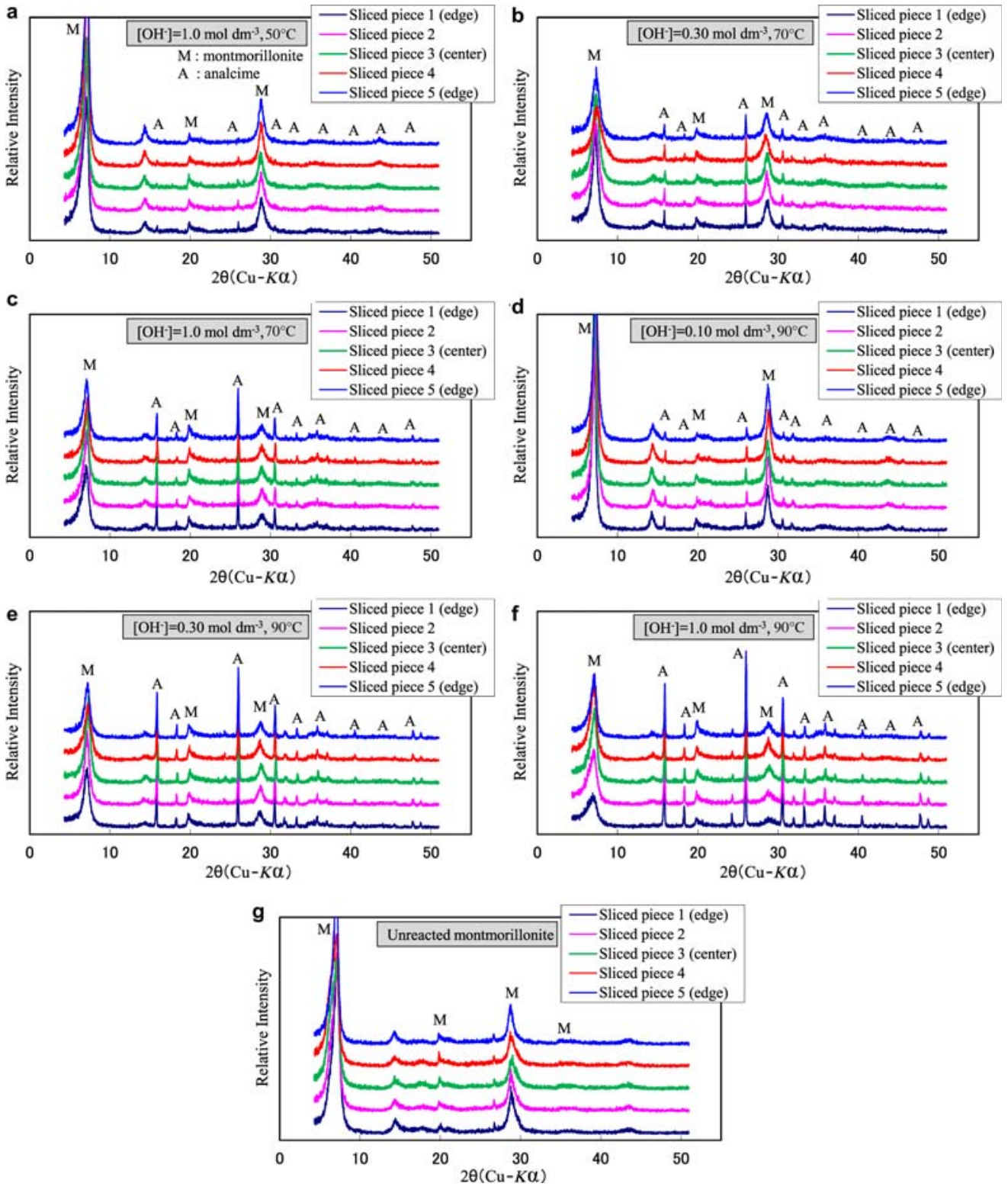

Fig. 3. Mineral compositions of the five slices analysed by XRD: (a) after 98 days, $\mathrm{OH}^{-}$concentration of $1.0 \mathrm{~mol} \mathrm{dm}^{-3}$ at $50^{\circ} \mathrm{C}$; (b) after 224 days, $0.30 \mathrm{~mol} \mathrm{dm}^{-3}$ at $70^{\circ} \mathrm{C}$; (c) after 84 days, $1.0 \mathrm{~mol} \mathrm{dm}^{-3}$ at $70^{\circ} \mathrm{C}$, (d) after 210 days, $0.10 \mathrm{~mol}$ $\mathrm{dm}^{-3}$ at $90^{\circ} \mathrm{C}$; (e) after 154 days, $0.30 \mathrm{~mol} \mathrm{dm}^{-3}$ at $90^{\circ} \mathrm{C}$; (f) after 56 days, $1.0 \mathrm{~mol} \mathrm{dm}{ }^{-3}$ at $90^{\circ} \mathrm{C}$; and (g) unreacted montmorillonite. M: montmorillonite, A: analcime.

nonahydrate $\left(\mathrm{Na}_{2} \mathrm{SiO}_{3} \cdot 9 \mathrm{H}_{2} \mathrm{O}\right)$ and small amounts of aluminium standard solution (Al concentration of $1000 \mathrm{mg} \mathrm{dm}^{-3}$ and $\mathrm{HNO}_{3}$ of $0.2 \mathrm{~mol} \mathrm{dm}^{-3}$ ) and calcium standard solution $(\mathrm{Ca}$ concentration of $1000 \mathrm{mg} \mathrm{dm}^{-3}$ and $\mathrm{HNO}_{3}$ of $0.1 \mathrm{~mol} \mathrm{dm}^{-3}$ ) to deionized water to obtain chemical compositions shown in
Table 2. Potassium, although usually present in cementitious water, was not added to the experimental solutions because the dissolution rate of montmorillonite in $\mathrm{KOH}-\mathrm{NaOH}$ mixed solutions where $\mathrm{K}$ feldspar was formed was identical to that in an $\mathrm{NaOH}$ solution (Yamaguchi et al., 2007). The specimen holder 

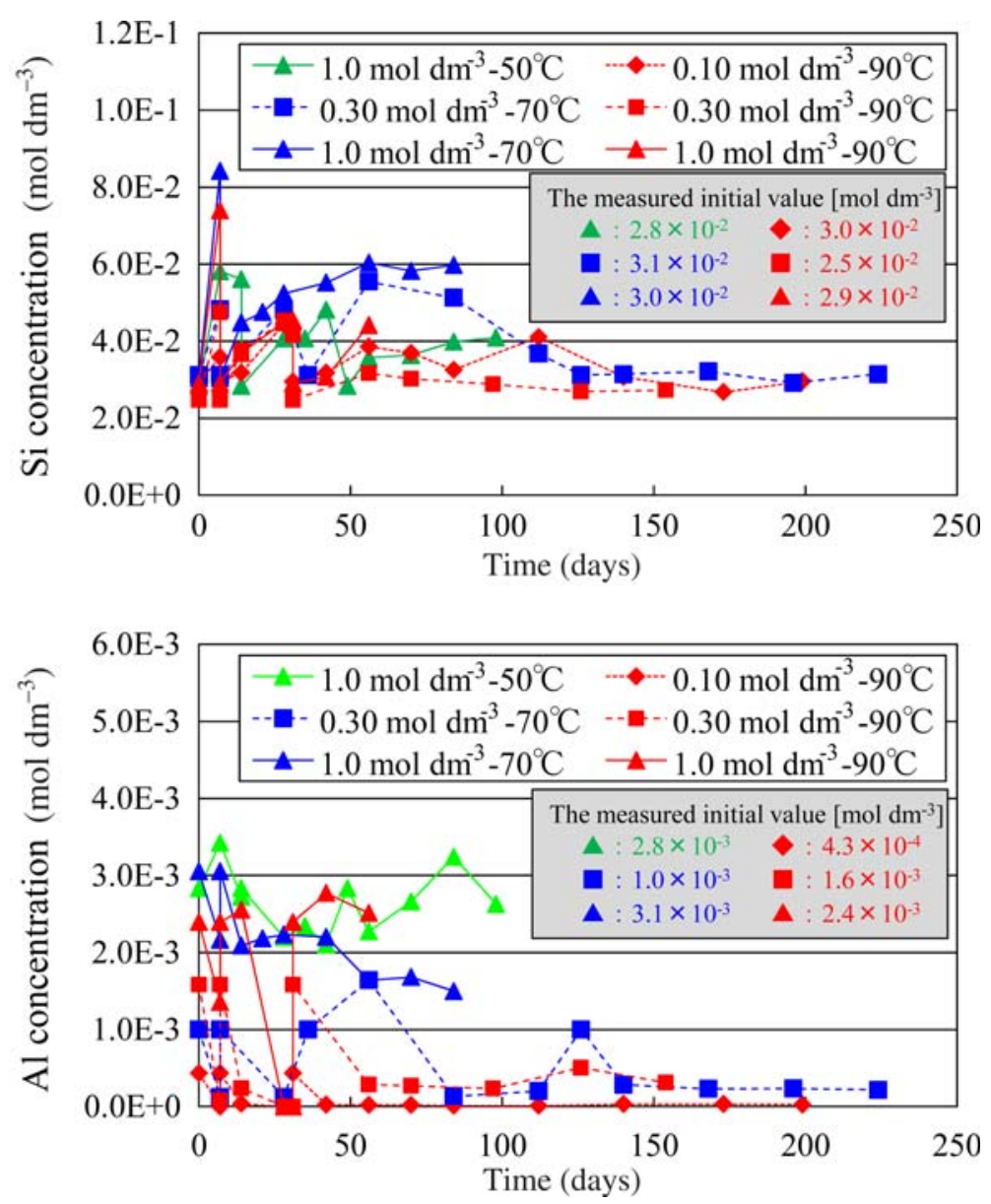

FIG. 4. Time courses of Si- and Al-concentrations in alkaline solutions used in the alteration experiment. The initial measured values of $\mathrm{Si}$ and $\mathrm{Al}$ concentrations are shown. In order to keep the variations of $\mathrm{pH}$ in the assemblies within \pm 0.2 , the alkaline solutions were replaced by fresh solutions after 14 - and 49 -day periods at $50^{\circ} \mathrm{C}\left(\mathrm{OH}^{-}\right.$concentration of $\left.1.0 \mathrm{~mol} \mathrm{dm}^{-3}\right), 7-, 36$ - and 126-day periods at $70^{\circ} \mathrm{C}\left(0.30 \mathrm{~mol} \mathrm{dm}^{-3}\right)$, 7-day period at $70^{\circ} \mathrm{C}\left(1.0 \mathrm{~mol} \mathrm{dm}^{-3}\right)$, and 7- and 31-day periods at $90^{\circ} \mathrm{C}\left(0.10,0.30\right.$ and $\left.1.0 \mathrm{~mol} \mathrm{dm}^{-3}\right)$.

was soaked in the alkaline solution in a $\operatorname{Teflon}^{\circledR}$ container assembly at room temperature under vacuum for 1 week to saturate the specimen (Fig. 1). Then, the assembly was contacted with $0.065 \mathrm{dm}^{3}$ of the alkaline solution in a sealed stainless steel container and kept at 50,70 and $90^{\circ} \mathrm{C}$ in an oven to observe montmorillonite dissolution over a reasonable time period. The alkaline solution was replaced by fresh solution when necessary to minimize changes in the concentration of $\mathrm{OH}^{-}$. The necessity was decided by monitoring the $\mathrm{pH}$ of mockup assemblies each week. When the measured value of $\mathrm{pH}$ decreased by $>0.1 \mathrm{pH}$ units from the initial value, the alkaline solution in all assemblies of the same condition was exchanged for the initial solution.
Therefore the variations of $\mathrm{pH}$ in the assemblies were kept within $\pm 0.2 \mathrm{pH}$ units, during the alteration period. The $\mathrm{pH}$ was measured at $\sim 25^{\circ} \mathrm{C}$ using a $\operatorname{ROSS}^{\circledR}$ combination-glass $\mathrm{pH}$ electrode (Orion 8172BNWP, Thermo Scientific, Inc., USA) calibrated with 7.00 and $10.01 \mathrm{pH}$ buffers and $1 \mathrm{~mol} \mathrm{dm}^{-3} \mathrm{NaOH}$ solutions. Each of the assemblies was taken from the oven at the fixed sampling time. The compacted montmorillonite specimen was pushed out from the holder by $2 \mathrm{~mm}$ at a time using a screw presser and was sliced with a steel blade. Each sliced piece was weighed, freeze-dried at $110^{\circ} \mathrm{C}$, ground using a mortar and pestle, redried at $90^{\circ}$ $\mathrm{C}$ and then analyzed for the amount of remaining montmorillonite by the conventional methylene-blue 


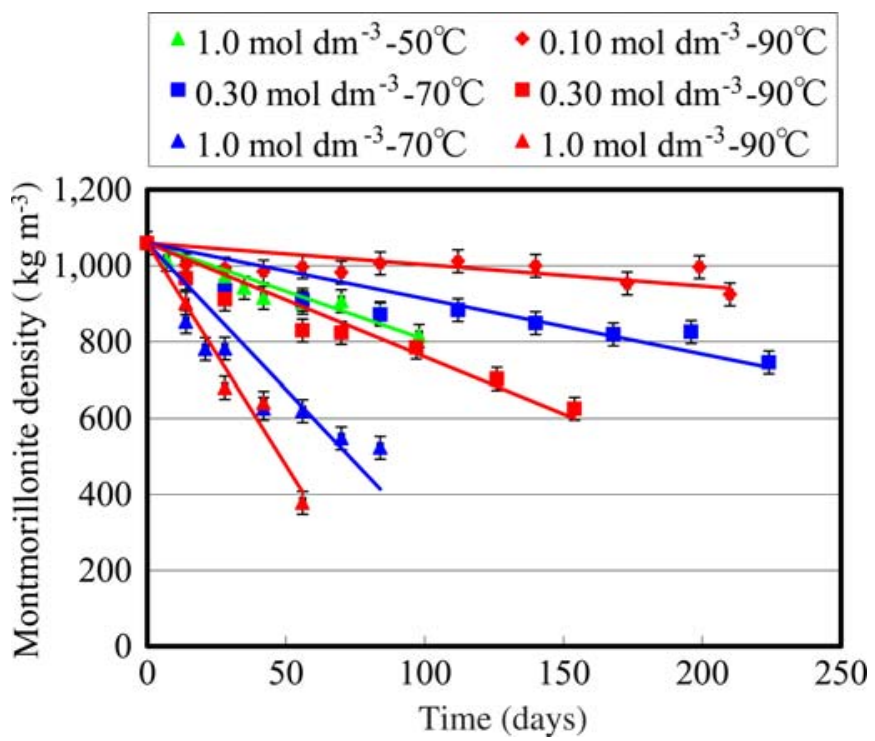

FIG. 5. Time courses of montmorillonite densities in compacted Kunipia-F under highly alkaline conditions. Bars represent the errors from the determination of the montmorillonite density by the methylene blue adsorption titration.

The straight lines were obtained by the least-squares method.

adsorption titration method (Hang \& Brindley, 1970; Brindley \& Thompson, 1970; Japan Bentonite Manufacturers' Association, 1991). In the present study, $2.5 \times 10^{-4} \mathrm{~kg}$ of crushed sample and of pure montmorillonite (Kunipia-F) for calibration were used. Furthermore, the remaining reacted solid was analyzed by powder X-ray diffraction (XRD, Geigerflex, Rigaku Corp., Japan). The concentrations of $\mathrm{Al}$ and $\mathrm{Ca}$ in the contacted aqueous solutions were determined by inductively-coupled plasma atomic emission spectroscopy (ICP-AES, SII SPS 7800, SII Nanotechnology Inc., Japan) after filtering the solutions through a $0.45 \mu \mathrm{m}$ PTFE (polytetrafluoroethylene) filter and acidifying into $0.5 \mathrm{~N} \mathrm{HNO}_{3}$. The concentration of $\mathrm{Si}$ was determined as $\mathrm{SiO}_{2}$ by means of the molybdosilicate method (Rand et al., 1976; Japanese Standard

TABLE 3. Dissolution rates of compacted montmorillonite under hydroxide ion concentrations of $0.10-1.0 \mathrm{~mol} \mathrm{dm}^{-3}$ and temperatures of 50 to $130^{\circ} \mathrm{C}$. The errors indicate a confidence limit of $68 \%(1 \sigma)$.

\begin{tabular}{cccccc}
\hline Temperature & $\begin{array}{c}\mathrm{OH}^{-} \text {concentration } \\
\left(\mathrm{mol} \mathrm{dm}^{-3}\right)\end{array}$ & $\begin{array}{c}\text { Activity of } \mathrm{OH}^{-} \\
\left(\mathrm{mol} \mathrm{dm}^{-3}\right)\end{array}$ & $\begin{array}{c}\text { Dissolution rate, } \\
R_{\mathrm{A}}\left(\mathrm{kg} \mathrm{m}^{-3} \mathrm{~s}^{-1}\right)\end{array}$ & $\begin{array}{c}\text { Alteration } \\
\text { period (day) }\end{array}$ & $\begin{array}{c}\text { Porosity } \\
\text { variations }\end{array}$ \\
\hline $50^{\circ} \mathrm{C}$ & 1.0 & 0.62 & $(2.9 \pm 0.6) \times 10^{-5}$ & 98 & $0.54-0.60$ \\
$(323.15 \mathrm{~K})$ & & & & & \\
$70^{\circ} \mathrm{C}$ & 0.30 & 0.22 & $(1.7 \pm 0.4) \times 10^{-5}$ & 224 & $0.52-0.60$ \\
$(343.15 \mathrm{~K})$ & 1.0 & 0.58 & $(8.9 \pm 2.1) \times 10^{-5}$ & 84 & $0.57-0.65$ \\
$90^{\circ} \mathrm{C}$ & 0.10 & 0.056 & $(6.6 \pm 3.5) \times 10^{-6}$ & 210 & $0.56-0.62$ \\
$(363.15 \mathrm{~K})$ & 0.30 & 0.20 & $(3.5 \pm 0.6) \times 10^{-5}$ & 154 & $0.56-0.61$ \\
& 1.0 & 0.56 & $(1.4 \pm 0.2) \times 10^{-4}$ & 56 & $0.55-0.60$ \\
$130^{\circ} \mathrm{C}^{2}$ & 0.10 & 0.057 & $(6.9 \pm 1.1) \times 10^{-5}$ & 162 & $0.45-0.60$ \\
$(403.15 \mathrm{~K})$ & 0.30 & 0.17 & $(3.8 \pm 0.5) \times 10^{-4}$ & 28 & $0.48-0.60$ \\
& 1.0 & 0.58 & $(8.8 \pm 1.4) \times 10^{-4}$ & 14 & $0.48-0.60$ \\
\hline
\end{tabular}

\footnotetext{
${ }^{1}$ Initial porosity was 0.60 .

${ }^{2}$ Previous dissolution rate data at $130^{\circ} \mathrm{C}$ (Sawaguchi et al., 2013).
} 
Association, 2004; The Japan Society for Analytical Chemistry Hokkaido, 1994) and by UV spectrometry (U-3210, HITACHI, Ltd., Japan) after the filtration.

\section{RESULTS AND DISCUSSION}

The weight of montmorillonite in each sliced piece ( $W_{\text {mont }}, \mathrm{kg}$ ) was determined using equation 1 :

$$
W_{\text {mont }}=W_{\text {dry }} \cdot V_{\text {titrb }}(\text { alter }) / V_{\text {titrb }}(\text { pure })
$$

where $W_{\text {dry }}$ is the dry weight of each slice $(\mathrm{kg})$, $V_{\text {titrb }}($ alter $)$ is the total volume of methylene-blue solution added to titrate the altered sample $\left(\mathrm{dm}^{3}\right)$, $V_{\text {titrb}}$ (pure) is the total volume of methylene-blue solution added to titrate the pure montmorillonite $\left(\mathrm{dm}^{3}\right)$. It is known empirically that slight differences in experimental procedure have a large influence on a result in the methylene-blue adsorption titration method (Miyoshi et al., 2015). In the present study, efforts were made to minimize errors: (1) by having a single analyst perform a series of experiments; (2) by following a standard testing method; and (3) by using a micropipette to drop the fixed amount of suspension on the filter paper. The error in the results of the titration was estimated to be $\pm 7.4 \times 10^{-6} \mathrm{~kg}$ at $1 \sigma$, which brings an error of $\pm 9.9 \times 10^{-5} \mathrm{~kg}$ at $1 \sigma$ into $W_{\text {mont }}$.

The montmorillonite content of each of the slices decreased with alteration time (Fig. 2). The XRD patterns of each slice also showed that the decrease in montmorillonite and the formation of secondary analcime $\left(\mathrm{NaAlSi}_{2} \mathrm{O}_{6}\right)$, proceeded over time (Fig. 3). The alteration of primary minerals proceeded both at the centre and the edges of the specimens facing the alkaline solution so that uniform dissolution of montmorillonite in the compacted specimens was considered hereafter. The diffusive mass transfer of $\mathrm{OH}^{-}$would be much greater than the rate of consumption in the compacted montmorillonite. The above-mentioned dissolution and formation of minerals is qualitatively consistent with the concentrations of $\mathrm{Si}$ and $\mathrm{Al}$ in the contacting solutions (Fig. 4). The concentrations of $\mathrm{Si}$ tend to be much greater than the initial values in all alkaline solutions, due to the dissolution of montmorillonite. The formation of analcime in the solutions rich in $\mathrm{Si}$ and $\mathrm{Na}$ concentrations probably consumed $\mathrm{Al}$, which decreased the $\mathrm{Al}$ concentration. Although determination of the concentration of $\mathrm{Ca}$ was difficult due to interference with the high-concentration of $\mathrm{Na}$, an increase in the concentrations of $\mathrm{Ca}$ was observed, probably due to the dissolution of montmorillonite, which contains $\sim 0.36$ wt. $\%$ of exchangeable Ca (Ito et al., 1993).

The amount of montmorillonite in the compacted montmorillonite decreased linearly with time over several months under the conditions of $\mathrm{OH}^{-}$concentration and temperature used (Fig. 5). The greater concentration of $\mathrm{OH}^{-}$in the external solution and/or temperature resulted in the faster, linear decrease in montmorillonite content in accordance with previous studies (Nakayama et al., 2004; Yamaguchi et al., 2007; Sawaguchi et al., 2013). The montmorillonite density can be expressed as:

$$
\rho(t)=\rho(0)-R_{A} t
$$

where $\rho(t)$ is the amount of montmorillonite in the altered compacted specimen $\left(\mathrm{kg} \mathrm{m}^{-3}\right), \rho(0)$ is the initial density $\left(\mathrm{kg} \mathrm{m}^{-3}\right), R_{A}$ is the dissolution rate of compacted montmorillonite $\left(\mathrm{kg} \mathrm{m}^{-3} \mathrm{~s}^{-1}\right)$ and $t$ is the time after the contact with the alkaline solution (s). The calculated dissolution rates by equation 2 are listed in Table 3 together with previous $R_{A}$ data at $130^{\circ} \mathrm{C}$ (Sawaguchi et al., 2013).

The concentrations of $\mathrm{OH}^{-}\left(\left[\mathrm{OH}^{-}\right],\left(\mathrm{mol} \mathrm{dm}{ }^{-3}\right)\right)$ in alkaline solutions were kept within \pm 0.2 logarithmic units by changing the water with the new one during the reaction. The measured values of $\mathrm{pH}, \mathrm{pHe}$, through experimental time were averaged and converted into

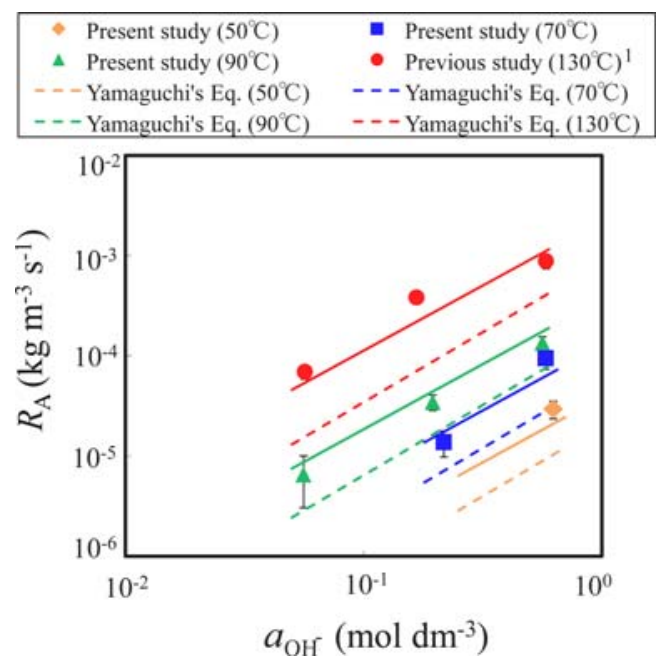

FIG. 6. Dependence of the dissolution rate of compacted montmorillonite, $R_{\mathrm{A}}\left(\mathrm{kg} \mathrm{m}^{-3} \mathrm{~s}^{-1}\right)$, on the activity of hydroxide ions, $a_{\mathrm{OH}^{-}}\left(\mathrm{mol} \mathrm{dm}^{-3}\right)$, and on temperature, $T$ (K). The solid curves are the calculated values using equation 3 . $^{1}$ Dissolution rate in compacted montmorillionite at $130^{\circ} \mathrm{C}$ (Sawaguchi et al., 2013). 

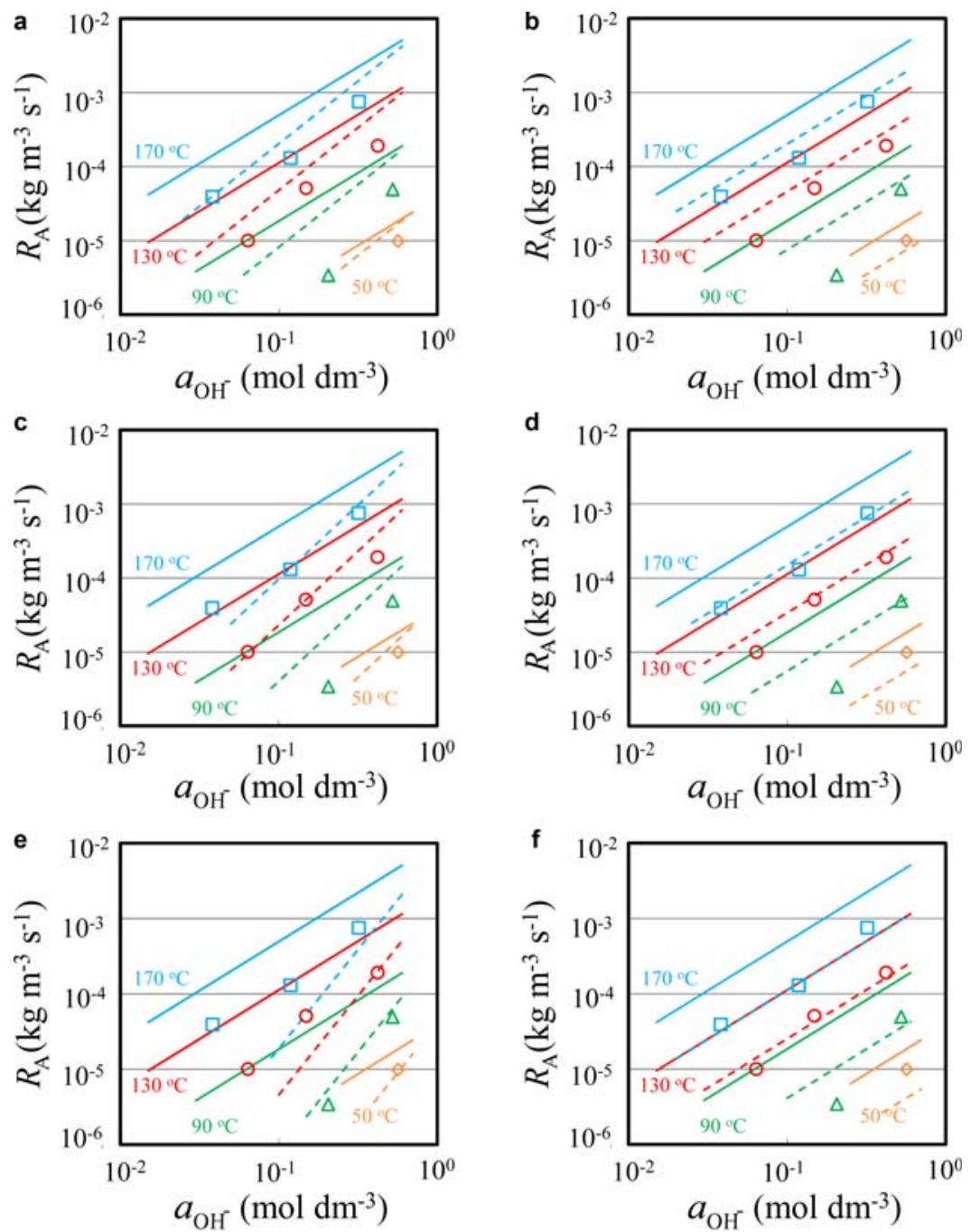

\begin{tabular}{|cc|}
\hline- Equation $3\left(50^{\circ} \mathrm{C}\right)$ & Equation $3\left(90^{\circ} \mathrm{C}\right)$ \\
- Equation $3\left(130^{\circ} \mathrm{C}\right)$ & - Equation $3\left(170^{\circ} \mathrm{C}\right)$ \\
-- Shifting equation $3\left(50^{\circ} \mathrm{C}\right)$ & -- Shifting equation $3\left(90^{\circ} \mathrm{C}\right)$ \\
-- Shifting equation $3\left(130^{\circ} \mathrm{C}\right)$ & -- Shifting equation $3\left(170^{\circ} \mathrm{C}\right)$ \\
$\diamond$ Yamaguchi's data $\left(50^{\circ} \mathrm{C}\right)$ & $\triangle$ Yamaguchi's data $\left(90^{\circ} \mathrm{C}\right)$ \\
$\circ$ Yamaguchi's data $\left(130^{\circ} \mathrm{C}\right)$ & $\square$ Yamaguchi's data $\left(170^{\circ} \mathrm{C}\right)$ \\
\hline
\end{tabular}

FIG. 7. Comparison between the dissolution rate of montmorillonite in the mixtures and the curves given by shifting equation 3: (a) by $0.05 \mathrm{~mol} \mathrm{dm}^{-3}$; (b) by $0.1 \mathrm{~mol} \mathrm{dm}^{-3}$; (c) by $0.2 \mathrm{~mol} \mathrm{dm}^{-3}$; (d) by shifting by 0.3 logarithmic units; (e) by 0.4 logarithmic units; and (f) by 0.5 logarithmic units.

$\left[\mathrm{OH}^{-}\right]$by the correlation equation between $\mathrm{pHe}$ and theoretically evaluated $\left[\mathrm{OH}^{-}\right]$of the initial solutions shown in Table 2: $\left[\mathrm{OH}^{-}\right]=10^{0.982 \times \mathrm{pHe}-13.6}$. Furthermore, representative values of activities of hydroxide ion, $a_{\mathrm{OH}}$, for each experimental condition were determined by multiplying $\left[\mathrm{OH}^{-}\right]$by the activity coefficients evaluated using the SIT (specific ion interaction) model (Lemire et al., 2001).

The dissolution rates of compacted montmorillonite, including previously obtained data at $130^{\circ} \mathrm{C}$, were 
formulated as a function of $\left.a_{\mathrm{OH}^{-}}(\mathrm{mol} \mathrm{dm})^{-3}\right)$ and temperature, $T(\mathrm{~K})$, by multiple regression analysis:

$$
R_{\mathrm{A}}=10^{(4.5 \pm 2.5)} \cdot\left(a_{\mathrm{OH}^{-}}\right)^{1.3 \pm 0.4} \cdot e^{(-55000 \pm 16000) / R T}
$$

where $\mathrm{R}$ is the gas constant $\left(8.314 \mathrm{~J} \mathrm{~mol}^{-1} \mathrm{~K}^{-1}\right)$. The errors indicate the confidence limit of $68 \%(1 \sigma)$. Equation 3 was compared with the formula of the dissolution rate of montmorillonite in the mixtures (Yamaguchi et al., 2007): $R_{\mathrm{A}}=3500 \cdot\left(a_{\mathrm{OH}^{-}}\right)^{1.4} \cdot e^{-51000 / \mathrm{R} T}$ (Fig. 6). The dissolution rate is greater in the compacted montmorillonite than in the mixtures. In a previous study performed at $130^{\circ} \mathrm{C}$ (Sawaguchi et al., 2013), the possibility that the dissolution of montmorillonite in the mixtures was inhibited by the increase of $\mathrm{Si}$ concentration in pore water and/or by the effect of the difference between bentonite specimens used in each experiment was ruled out. Therefore the difference in dissolution rates would be caused by the negative shift of, or decrease in, $a_{\mathrm{OH}}-$ in the mixtures accompanied by dissolution of accessory minerals such as $\mathrm{SiO}_{2}$ polymorphs.

Assuming that the shift would be linear by $0.05,0.1$ or $0.2 \mathrm{~mol} \mathrm{dm}^{-3}$ or logarithmic by $0.3,0.4$ or 0.5 units, the dissolution rates of montmorillonite in the mixtures were estimated (Fig. 7). The curves given by shifting equation 3 by $0.05 \mathrm{~mol} \mathrm{dm}^{-3}$ and by 0.4 logarithmic units reproduce the dissolution rate data in the mixtures well. Furthermore, trial calculations by considering the shift of $a_{\mathrm{OH}^{-}}$were performed to reproduce the montmorillonite dissolution experiment of Yamaguchi et al. (2013), who compacted sandbentonite mixture specimens immersed in $1 \mathrm{~mol} \mathrm{dm}^{-3}$ $\mathrm{NaOH}$ solution at $90^{\circ} \mathrm{C}$ for $14,27,51$ and 67 days. Figure 8 shows the montmorillonite densities after each alteration period and the calculated values obtained using the dissolution rates from equation 3 and those after shifting. The calculated values obtained by shifting equation 3 by 0.3 logarithmic units reproduced the experimental data better than by $0.05 \mathrm{~mol} \mathrm{dm}^{-3}$. These results indicate that the dissolution rate in the mixtures can be explained by equation 3 considering a shift of the $a_{\mathrm{OH}^{-}}$in the mixtures, and that the shift may be logarithmic. The shift in logarithmic scale is more consistent than the shift in linear scale with the dependence on compacted montmorillonite, $1.3 \pm 0.4$, being closer to that for the mixtures, $1.4 \pm 0.3$. The shift in linear scale is not favoured because it gives an extremely low dissolution rate when applied to lower $\mathrm{pH}$ ranges.

The activation energy obtained $(55 \pm 16 \mathrm{~kJ} / \mathrm{mol})$ is consistent with that reported for the mixtures $(51 \mathrm{~kJ} / \mathrm{mol}$, Yamaguchi et al., 2007) and with that determined for smectite dissolution in $\mathrm{KOH}$ solution $(52 \pm 4 \mathrm{~kJ} / \mathrm{mol}$, Bauer \& Berger, 1998).

Yamaguchi et al. (2007) compared the formula of dissolution rate of montmorillonite in the mixtures with that of pure pulverized montmorillonite determined by flow-through experiments (Sato et al., 2004) and pointed out that the difference in the dependence on $a_{\mathrm{OH}}-$ made a large difference in the dissolution rate when the dependence was extrapolated to repository conditions. The formula obtained in the present study also gives a much lower dissolution rate than Sato et al. (2004) for $a_{\mathrm{OH}^{-}},<0.01 \mathrm{~mol} \mathrm{dm}^{-3}$. However it gives greater dissolution rate than Yamaguchi et al. (2007) by $\sim 0.3$ orders of magnitude.

In the present study, the dissolution rate of montmorillonite free of accessory minerals, under compacted conditions was formulated. In order to
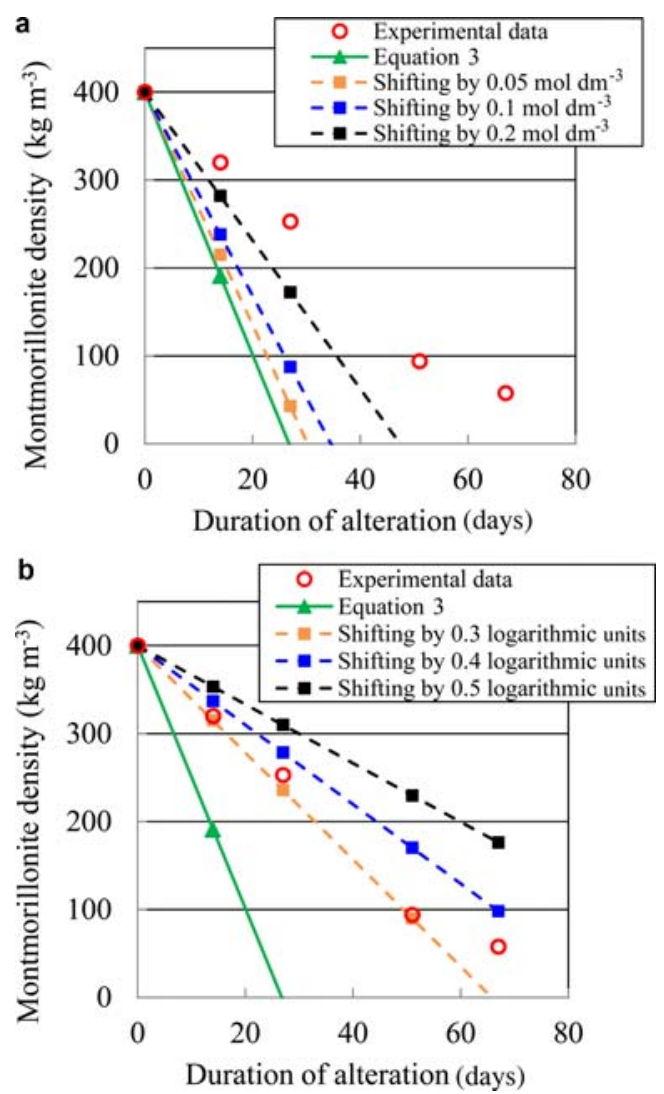

FIG. 8. The results of dissolution experiments for the compacted sand-bentonite mixtures (Yamaguchi et al., 2013) and the calculation values evaluated using equation 3 taking into account shifting of $a_{\mathrm{OH}^{-}}$: (a) $0.05,0.1$ or $0.2 \mathrm{~mol} \mathrm{dm}^{-3}$; and (b) $0.3,0.4$ or 0.5 logarithmic units. 
provide reliable values for the long-term prediction of bentonite buffer performance under disposal conditions by using the dissolution rate equation, further study is necessary to quantify the decrease in $a_{\mathrm{OH}^{-}}$ accompanied by dissolution of accessory minerals such as $\mathrm{SiO}_{2}$ polymorphs.

\section{CONCLUSIONS}

The dissolution rate of the compacted montmorillonite (Kunipia-F) was formulated as a function of $a_{\mathrm{OH}}{ }^{-}$and temperature. The existence of accessory minerals decreased the dissolution rate of montmorillonite. The dissolution rate model developed can be used not only for pure montmorillonite but also for bentonite mixtures by taking into account the negative shift of $a_{\mathrm{OH}^{-}}$in the mixtures accompanied by dissolution of accessory $\mathrm{SiO}_{2}$ polymorphs.

\section{ACKNOWLEDGEMENTS}

Part of this research was funded by the Secretariat of Nuclear Regulation Authority, Nuclear Regulation Authority, Japan (formerly the Nuclear and Industrial Safety Agency, Ministry of Economy, Trade and Industry, Japan). The authors acknowledge Drs Hisayoshi Mitamura and Tetsushi Nagano for performing the longterm experiments at the Waste Safety Testing Facility (WASTEF) of the Japan Atomic Energy Agency. Dr Logan Barr of the Japan Atomic Energy Agency is acknowledged for improving the English. Anonymous referees are acknowledged for their work on the manuscript and their helpful comments.

\section{REFERENCES}

Bauer A. \& Berger G. (1998) Kaolinite and smectite dissolution in high molar $\mathrm{KOH}$ solutions at $35^{\circ} \mathrm{C}$ and $80^{\circ} \mathrm{C}$. Applied Geochemistry, 13, 905-916.

Brindley G.W. \& Thompson T.D. (1970) Methylene blue absorption by montmorillonites. Determinations of surface areas and exchange capacities with different initial cation saturations (clay-organic studies XIX). Israel Journal of Chemistry, 8, 409-415.

Hang P.T. \& Brindley G.W. (1970) Methylene blue absorption by clay minerals. Determination of surface areas and cation exchange capacities (clay-organic studies XVIII). Clays and Clay Minerals, 18, 203-212.

Ito M., Okamoto M., Shibata M., Sasaki Y., Danhara T., Suzuki K. \& Watanabe, T. (1993) Mineral Composition Analysis of Bentonite. PNC TN 8430 93-003, Power Reactor and Nuclear Fuel Development, Corporation, Tokyo (in Japanese).
Japan Bentonite Manufacturers Association (1991) JBAS107-91 Measuring Method of Methylene Blue Adsorption Value of Bentonite. pp. 1-5 (in Japanese). Japanese Standard Association (2004) 44 Silica $\left(\mathrm{SiO}_{2}\right)$, JIS K 0101 Testing method for industrial water. pp. 468-473 in: JIS Handbook 53, Environmental Technology II (Water Contamination), 2004, Japanese Standard Association, Tokyo (in Japanese).

Kubo H., Kuroki Y. \& Mihara M. (1998) Experimental investigation on alteration of bentonite by concrete pore fluids. Tsuchi-to-Kiso, The Japanese Geotechnical Society, 46, 31-34 (in Japanese).

Lemire R.J., Fuger J., Nitsche H., Potter P., Rand M.H., Rydberg J., Spahiu K., Sullivan J.C., Ullman W., Vitorge P. \& Wanner, H. (2001) Chemical Thermodynamics of Neptunium and Plutonium, pp. 800-810, Elsevier, Amsterdam.

Miyoshi Y., Horiuchi Y. \& Takagi T. (2015) Present state of methylene-blue adsorption-test for bentonite in Japan. Journal of the Clay Science Society of Japan, 53, 26-36 (in Japanese).

Nakayama S., Sakamoto Y., Yamaguchi T., Akai M., Tanaka T., Sato T. \& Iida Y. (2004) Dissolution of montmorillonite in compacted bentonite by highly alkaline aqueous solutions and diffusivity of hydroxide ions. Applied Clay Science, 27, 53-65.

Rand M.C., Greenberg A.E., Taras M.J. \& Franson M.A. (1976) Standard Methods for the Examination of Water and Wastewater. American Public Health Association, Washington, DC, pp. 484-492.

Rozalén M.L., Huertas F.J., Brady P.V., Cama J., GarciaPalma S. \& Linares J. (2008) Experimental study of the effect of $\mathrm{pH}$ on the kinetics of montmorillonite dissolution at $25^{\circ} \mathrm{C}$. Geochimica et Cosmochimica Acta, 72, 4224-4253.

Rozalén M., Huertas F.J. \& Brady P.V. (2009) Experimental study of the effect of $\mathrm{pH}$ and temperature on the kinetics of montmorillonite dissolution. Geochimica et Cosmochimica Acta, 73, 3752-3766.

Sato T., Kuroda M., Yokoyama S., Tsutsui M., Fukushi K., Tanaka T. \& Nakayama S. (2004) Dissolution mechanism and kinetics of smectite under alkaline conditions. In: Proceedings of the International Workshop on Bentonite-Cement Interaction in Repository Environment, 14-16 April 2004, Tokyo, NUMO-TR-04-05, pp. A3-38-A3-41.

Savage D. \& Liu J. (2015) Water/clay ratio, clay porosity models and impacts upon clay transformations. Applied Clay Science, 116-117, 16-22.

Savage D., Bateman K., Hill P., Hughes C., Milodowski A., Pearce J., Rae E. \& Rochelle C. (1992) Rate and mechanism of the reaction of silicates with cement pore fluids. Applied Clay Science, 7, 33-45.

Sawaguchi T., Kadowaki M., Yamaguchi T., Mukai M. \& Tanaka T. (2013) Alkaline dissolution behaviour of montmorillonite under compacted conditions. Journal 
of Nuclear Fuel Cycle and Environment, 20, 71-78 (in Japanese).

The Japan Society for Analytical Chemistry Hokkaido (1994) Analysis of Water, 4th edition. Kagaku-Dojin Publishing Company, Inc., Kyoto, Japan, pp. 181-184 (in Japanese).

Yamaguchi T., Sakamoto Y., Akai M., Takazawa M., Iida Y., Tanaka T. \& Nakayama S. (2007) Experimental and modeling study on long-term alteration of compacted bentonite with alkaline groundwater. Physics and Chemistry of the Earth, 32, 298-310.

Yamaguchi T., Sawaguchi T., Tsukada M., Kadowaki M. \& Tanaka T. (2013) Changes in hydraulic conductivity of sand-bentonite mixtures accompanied by alkaline alteration. Clay Minerals, 48, 403-410. 